\title{
Создание резонаторов для мод шепчущей галереи методом сильного изгиба оптического волокна
}

\author{
Д.В. Бочек $^{1, *}$, И.Д. Ватник ${ }^{1}$, Д.В. Чуркин ${ }^{1}$, М. Сумецкий ${ }^{2}$ \\ ${ }^{1}$ Новосибирский государственный университет \\ ${ }^{2}$ Aston Institute of Photonic Technologies, Aston University \\ *E-mail: dashabocheck@gmail.com
}

В докладе рассматриваются компактные устройства на основе наноразмерных поверхностных деформаций оптического волокна, которые образуют высокодобротные резонаторы для мод шепчущей галереи (МШГ). В отличие от обычных МШГ резонаторов, представленных микросферами, микродисками и микротороидами, в оптическом волокне с медленно распределенной вариацией эффективного радиуса (ВЭР) свет циркулирует вокруг его поверхности, претерпевая медленное распространение вдоль оси волокна. Аксиальное распространение МШГ полностью контролируется внесенной ВЭР, которая включает в себя вариацию показателя преломления и вариацию геометрических размеров оптического волокна. Такое аксиальное распределение МШГ внутри ВЭР описывается одномерным стационарным уравнением Шрёдингера [1]. Плавное наномаштабное распределение эффективного радиуса может быть изготовлено на поверхности оптического волокна с беспрецедентной субангстремной точностью [2] с помощью локального нагрева $\mathrm{CO}_{2}$ лазером или методом фемтосекундной записи [3]. Высокая точность внесения ВЭР в сочетании с высокой добротностью получаемых микрорезонаторов позволяет создавать сложные и миниатюрные фотонные устройства с перспективными приложениями в коммуникациях, квантовых вычислениях и многих задачах детектирования.

В данной работе мы предлагаем новый метод внесения ВЭР на оптическом волокне. Наш подход существенно проще уже существующих методов и состоит в контролируемом изгибе оптического волокна. Мы показали численно и экспериментально, что в сильно изогнутом оптическом волокне возникает ВЭР порядка нанометра, вызванная деформацией и эластооптическим эффектом. Благодаря тому, что получающаяся ВЭР имеет положительный знак, локальный изгиб волокна создает резонатор для МШГ с ненулевой аксиальной компонентой волнового вектора. Характеристики такого резонатора можно перестраивать за счет изменения его формы дополнительным изгибом. Кроме того, предложенный метод может использоваться для изменения характеристик МШГ резонаторов, изготовленных другими методами.

C помощью моделирования в среде COMSOL мы определили величину ВЭР для изогнутого стандартного телекоммуникационного волокна с диаметром оболочки 125 мкм. Результаты численного счета показали, что изгиб волокна с радиусом кривизны 1 см вводит положительную ВЭР, равную 4 нм, что достаточно для создания резонатора для МШГ с ненулевыми продольными волновыми числами. Вообще говоря, зависимость ВЭР от профиля изгиба волокна не является локальной и может быть найдена из решения нелинейных уравнений теории упругости.

Для экспериментального определения ВЭР изогнутого волокна мы измеряли его спектры МШГ последовательно вдоль оси волокна. Два кончика небольшого отрезка стандартного телекоммуникационного оптического волокна были закреплены в тонкой трубочке, таким образом волокно приобретало форму петли. При такой конфигурации изгиба кривизна волокна имеет плавное 
распределение с максимумом в центре петли. МШГ возбуждались с помощью растянутого биконического оптического микроволокна [4] с диаметром перетяжки $\sim 2$ мкм, которое подводилось перпендикулярно к поверхности образца. Спектр пропускания микроволокна при этом содержит провалы, соответствующие резонансным длинам волн МШГ в данной точке образца. Спектры пропускания микроволокна были измерены для разных точек вдоль всей петли с шагом в 250 мкм. На рисунке 1 представлены спектры МШГ резонатора, изготовленного с помощью изгиба волокна, построенные вдоль длины волокна. Из рисунка 1 видно, что ВЭР изогнутого волокна с хорошей точностью линейно зависит от его кривизны в данной точке, а её величина согласуется с оценками.

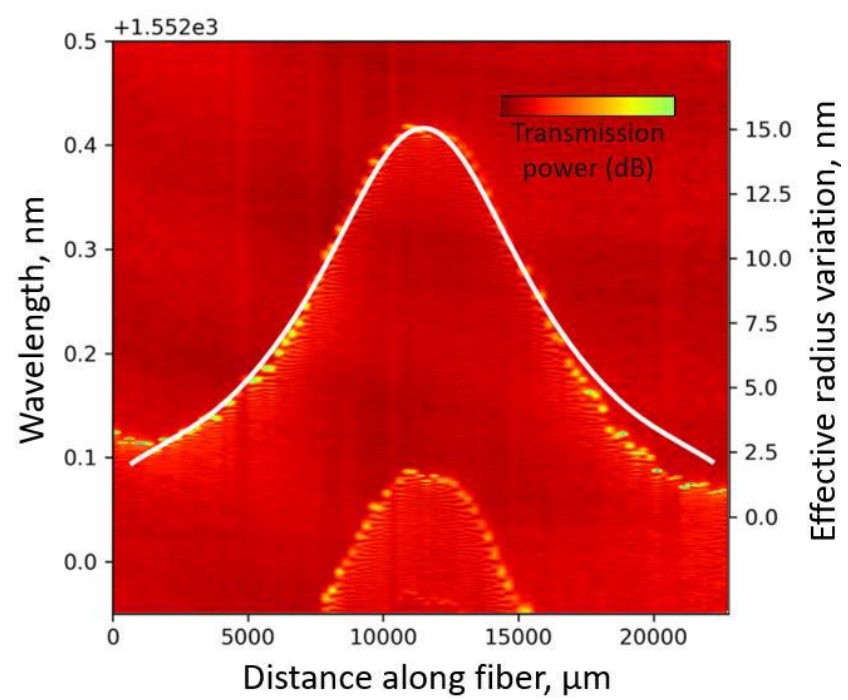

Рис.1. Спектры пропускания, измеренные в разных точках поверхности вдоль оси изогнутого волокна. Вариация эффективного радиуса (правая шкала) связана с изменением резонансной длины волны моды шепчущей галереи (левая шкала) как $\Delta r_{e f f}=r_{0} / \lambda_{0} * \Delta \lambda$. Белая линия зависимость локальной кривизны от координаты вдоль оси изогнутого волокна.

Таким образом, в данной работе мы продемонстрировали возможность изготавливать резонаторы для МШГ с ненулевой аксиальной компонентой волнового вектора методом сильного изгиба оптического волокна. Такие структуры на поверхности волокна могут иметь различные аксиальные распределения за счет создания изгибов сложной формы, а также перестраиваться благодаря точным механическим манипуляциям с концами резонатора. Простота разработанного нами метода и возможность контролируемо изменять параметры резонатора имеют большое значение для создания высокоточных и перестраиваемых фотонных устройств для различных применений в управлении оптическими сигналами и задачах детектирования.

Работа выполнена при поддержке РНФ (18-72-10053)

\section{Литература}

[1] M. Sumetsky, Nanophotonics 2, 393 (2013).

[2] N. A. Toropov, and M. Sumetsky, Opt. Lett. 41, 2278 (2016).

[3] F. Shen, X. Shu, L. Zhang, and M. Sumetsky, Opt. Lett. 41, 2795 (2016).

[4] J. C. Knight, G. Cheung, F. Jacques, and T. A. Birks, Opt. Lett. 22(15), 1129-1131 (1997)

[5] O. Boyraz, J. Kim et al, J. Lightwave Technology 18, 2167-2175 (2000) 